\title{
Neuropathy and cough may not be a fortuitous association
}

\author{
Neuropatia e tosse pode não ser uma associação fortuita \\ Wilson Marques-Jr
}

Faculdade de Medicina de Ribeirão Preto, Universidade de São Paulo, Sao Paulo SP, Brazil.

\section{Correspondence:}

Wilson Marques Jr.; Rua K, 165

Cond. 5 da Boa Vista: 14033-160 Ribeirão Preto SP - Brasil.

E-mail:wmjunior@fmrp.usp.br

\section{Conflict of interest:}

There is no conflict of interest to declare.

Received 14 March 2014

Accepted 21 March 2014

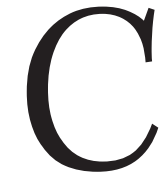
oexistence of neuropathy and chronic cough seems to be rare, but a series of recent reports have shown that it certainly occurs more frequently that we would expect by a chance association. As is the rule in neurogenetics, this coexistence seems to be associated to phenotypic and genotypic heterogeneity.

At least 2 reports described the existence of cough and a sensory and motor neuropathy, either related to a specific mutation in MPZ gene ${ }^{1}$ or to an unknown locus ${ }^{2}$.

More frequently, however, cough is a manifestation of an autosomal dominant hereditary sensory and autonomic neuropathy type 1 (HSAN1), also known as hereditary sensory neuropathy type 1 (HSN1). This is also a very heterogeneous condition and at least 5 genes have been recognized. HSN1B is the subtype associated to cough and gastroesophageal reflux (GOR).

HSN1B has been reported a few times in the literature and some families have been mapped to 3p22-p24 region ${ }^{3}$. Nine new families were recently presented at the $5^{\text {th }}$ CMT Consortium Meeting in Belgium (2013) by Beaudonnet et al. (personal communication) but no molecular data has been presented.

Clinically, it seems to exist considerable variability. Tendon jerks may be normal, brisk or absent; not always cough is associated to GOR; some may have impotence and/or urinary urgency or even urinary incontinency; sensorineural hearing loss may be a manifestation; sensory involvement may reflect a small fiber neuropathy and/or a large fiber neuropathy with sensory ataxia.

In this number of Arquivos de Neuropsiquiatria, Barros et al. ${ }^{4}$ described a Portuguese family with HSN1 and cough/GOR, clearly contributing to the clinical definition of this condition. Their patients had a severe sensory ataxia and a sensorineural loss was present on audiometry. Unfortunately no linkage data was presented.

A major contribution of gene identification of the hereditary neuropathies was a better understanding of the biology of the peripheral nervous system. Identification of the gene/genes responsible for these neuropathies certainly will contribute to build the biology of the sensory and autonomic neurons, to identify its similarities and to identify their similarities and differences with the motor neurons. Interestingly, some motor neuronopathies may present autonomic dysfuction $^{5}$. As a second contribution, gene identification will show if the clinical variability is due to genetic heterogeneity or if mutations in only one gene are associated to this large spectrum of clinical manifestations.

Finally, to those old neurologists that still see neurological examination as a fundamental step of a proper patient evaluation, or to those new neurologists that want to proper evaluate their patients, the Arnold's sign will certainly add a beautiful refinement. 


\section{References}

1. Baloh RH, Jen JC, Kim G, Baloh RW. Chronic cough due to Thr124Met mutation in the peripheral myelin protein zero (MPZ gene). Neurology 2004;62:1905-1906.

2. Miura S, Shibata $H$, Kida $H$, et al. Hereditary motor and sensory Neuropathy with proximal dominancy in the lower extremities, urinary disturbance and dry cough. J Neurol Sci 2008;273:88-92.

3. Kok C, Kennerson ML, Spring PJ, et al. A locus for hereditary sensory neuropathy with cough and gastrooesophageal reflux on chromosome 3q22-p24. Am J Hum Genet 2003;73:632-637.
Barros P, Morais H, Santos C, Coutinho P. Clinical and neurophysiologic characterization of an European Family with sensory Neuropathy, paroxysmal cough and gastroesophageal reflux. Arq Neuropsiquiatr 2014;72:269-272.

5. Marques VD, Barreira AA, Davis MB, et al. Expanding the phenotypes of the VAPB mutation: proximal SMA with dysautonomia. Muscle Nerve 2006;34:731-739. 